\title{
THE IMPACT OF ACADEMIC TRAINING PROGRAMMES IN IMPROVING TEACHING AND LEARNING: A CASE OF ACADEMIC STAFF AT A SELECTED UNIVERSITY OF TECHNOLOGY
}

\author{
L. Bingwa* \\ e-mail: Luyandab@dut.ac.za / https://orcid.org/0000-0001-6577-8460
}

\section{Ngibe*}

e-mail: musawenkosin1@dut.ac.za / https://orcid.org/0000-0002-4954-1460

*Department of Information and Corporate Management

Durban University of Technology

Durban, South Africa

\section{ABSTRACT}

Academic staff are required to change and adopt new teaching approaches to meet the requirements and expectations set by higher education institutions. This means that there is a drastic need for academics to be competent to help boost their teaching abilities, knowledge, and be encouraged to upgrade their qualifications. Without continuous well-coordinated academic training programmes, training, and skills development, academics will continuously struggle to perform their core functions which include research, teaching and learning, continuous professional development, and community engagement. The intention of this study therefore, is to identify academics perceptions on academic training programmes provided by the selected university of technology and the predicaments, and the complexities involved in empowering academics to improve their teaching and learning approaches. A quantitative research approach was therefore used, with a questionnaire used as a data collection instrument. Using a nonprobability purposive sampling technique, a sample size of 132 was considered.

The study findings revealed that the university lacked a proper system to evaluate and measure the impact of academic training programmes offered to academic staff. The recommendations were made on different aspects in line with the findings and the study aims and objectives. But most significantly, the study recommended that a systematic review should be done to monitor the impact these training programmes have on the development and support of teaching and learning

Keywords: training development, academic performance, higher education

\section{INTRODUCTION}

With the constant and forever changing environment in the higher education sector, academics are expected to be equipped relentlessly with the knowledge and aptitudes, and for this to be 
possible, the institution firstly needs to identify their staff developmental needs that would have to be addressed by the academic training program (Al-adwan and Smedley 2012; Salah 2016). This means that higher education institutions should restructure themselves and integrate to the needs and demands of the business industries, society, and relevant stakeholders by revamping their curriculum and providing clear objectives of the university and the role expected to be played by academics (Seyoum 2012). For this to be initiated and be achievable, continual skills training and development should be a forefront applied strategy (Newland and Byles 2014).

Universities are known for producing graduates as a product of teaching and learning in the preparedness of the workplace (Finch et al. 2016). Due to the current transformation and changes in teaching and learning, academics are increasingly demanded to be trained in order to be at par with those transformations, particularly having adequate technical skills to be able to operate technological equipment that has been introduced as an enhancer to teaching and learning in higher education (Balyer, Özcan, and Yildiz 2017). It is therefore, imperative to understand that training and development do not only enrich academic skills and performance of academics in their core disciplines, but these developmental programmes also motivate staff to work towards reaching the set goal of the institution (Asfaw, Argaw, and Bayissa 2015; Kumar and Siddika 2017). These academic training programmes allow academics to reach their full potential, helps them discover their academic limitations, and address them through the impartation of knowledge gained from training developmental programmes offered by the institution (Balyer, Özcan, and Yildiz 2017). Salah (2016) asserts that academic training and developmental programmes are an institutional effort of improving the quality and standard of teaching and learning and further to enhance staff academic skills, knowledge, and competencies, allows for new and effective teaching styles that make it easier to disseminate information in a way that students can grasp (Paolini 2015).

As stated by AL-Mutairi (2011) and Kang'ahi et al. (2012) lecturer competence is a critical factor that has a huge bearing on students' academic performance. This reflects that universities should have well-skilled academics for quality teaching and learning and most importantly for the betterment of student success rate. Therefore, higher learning institutions need to place a great emphasis on improving the knowledge and competencies of academic staff if they are to achieve the delivery of equality education and throughput rates. Hanaysha (2016) argues that this can only be achieved if academic training programmes are aligned with the specific needs of the lecturers. This study, therefore, intends to determine academic workshops and training programmes offered by the selected university of technology and their impact in informing their teaching and learning of students in the selected UoT's. 


\section{Primary research aim and objectives}

The primary aim of this study is to determine the impact of academic training programmes toward teaching and learning at a selected university of technology. In order to accomplish the primary aim of this study, the subsequent objectives will be pursued and addressed;

- To ascertain academic staff training programmes offered by the institution to enhance teaching and learning, and

- To determine the impact of academic staff training towards teaching and learning at the selected university of technology.

\section{LITERATURE REVIEW}

The higher education purpose is to produce knowledgeable and skilled graduates and also prepares them for the workplace, but not limited to that, it also has to ensure proper dissemination of knowledge and that lecturers are equipped with the necessary skills (Chan 2016). Moloi, Mkwanazi, and Bojabotseha (2014) postulate that higher education not only has to do with producing marketable, skilled graduates but also to improve the quality of teaching and learning and to retain academics that are intellectuals, who are not only focusing on teaching and learning but academics who partake in community engagement activities and research output. CHE (2013) report reflects that South African higher education institutions are created to address the learning needs and goals of students through the advancement of their intellectual abilities and aptitudes throughout their existence.

\section{TRAINING OF ACADEMIC STAFF A NECESSITY IN HIGHER EDUCATION}

Academic training is becoming a necessity for every institution, especially since academics are constantly assigned to different portfolios with different roles and responsibilities. Thus, training should be a part of the strategic planning of most organisations as requirements undergo endless changes (Karthikeyan, Karthi, and Graf 2010). These authors further claim that the success of any training programme is largely dependent on the training process and the awareness of the facilitator about the objectives of the training and how the training will benefit the participants and the institution. This is why urgent emphasis has been placed on capacity workshops, training, and development that addresses the needs of academic staff(Williams and Williams 2011).

Higher education institutions should consider training and development of academic staff essential and as a critical component that informs teaching and learning. As stated by Akinfolarin (2014) education evolves and requires academic staff to integrate and meet the 
needs of both students and the university. These transitions require academics to have comprehensive field knowledge, experience in teaching and learning, the aptitudes necessary to monitor and support students, and an understanding of the social and cultural dimensions of education (Fernández 2013). Conversely, limited training results in staff being demotivated, and unproductive, which hinders the staff's abilities to contribute significantly towards quality education, teaching, and learning (Salah 2016).

\section{ACADEMIC STAFF TRAINING PROGRAMMES}

A structured and proper training programme is an effort by the employer to afford opportunities for the employees to obtain job-related skills and knowledge. This indicates that for any organisation to successfully achieve the intentions of its training programmes, the design and implementation of those programmes should be custom-made towards improving performance and yield a great and desired output. Wickramasinghe (2006) and Rahman et al. (2013) claim that post-training exercises are key in establishing whether staff development training was successfully received by the employees.

So, effective training is one that enhances staff performance by connecting the gap between staff current performance and the desired future standard performance to ensure an adequate supply of staff that is technically, socially competent, and capable of career development into specialist departments or management positions. Therefore, there is a constant necessity for the process of staff development, and training to be viewed as an integral part of the process of total quality management (Elnaga and Imran 2013; Sabir et al. 2014). Furthermore, for employees to be innovative and effective on the job, they must be equipped with specific skills and knowledge suitable for the working environment and the management needs to be committed and periodically work on ensuring that these training workshops are beneficial to the employees and add value to organisations objectives (McDdowall and Saunders 2010; Elnaga and Imran 2013).

\section{TEACHING DYNAMICS IN HIGH EDUCATION}

\section{Learner-centred}

Academics are confronted by a various challenge, especially of encouraging students to be critical thinkers, and ensuring that the teaching and learning process promotes a learnercentered approach, which encourages students to be more active learners who are involved in their learning, students who learn through participation and academics should be knowledgeable on how to give assessments that encourage critical thinking (Winach and Meyer 
2013).

Literature shows that the incorporation of teaching styles that are learner-centered makes learning interesting as students now are becoming more hands-on, as it, improves students' engagement, enables them to be critical thinkers and problem solvers (Costly 2014).

Randall and Cox (2015) are of the view that lecturers who use a learner-centered approach believe that for effective teaching and learning processes to occur, students need to show a certain level of maturity and accountability for their learning in order to have a conducive learning experience. Furthermore, this method of teaching and learning promotes creativity, develops problem-solving skills, and encourages academics to consider students learning preferences when teaching. Abdelmalak and Trespalacios (2013) attest that a learner-centered approach not only focuses on what the student is learning but focuses on how they learn, the ability to retain the information learned, and to apply the knowledge.

\section{SUBJECT KNOWLEDGE}

Having sound subject knowledge is a requirement for effective teaching and learning because it enables the lecturer to critically deliver content in a way that best benefits students' academic needs (Ball and McDiarmid 2016).

So, having an extensive subject knowledge helps academics to ensure that their subject knowledge caters for students' academic needs, as this will impact subject delivery and thereby impact on student's success and for the aforementioned to be successful, training is vital for academics to equip them with the necessary skills. Furthermore, the academia's task is to ensure that subject design includes and also promote the following, if not limited to it, the student, content, activities, assessment, skills, and competencies, all the above mentioned should be added in the training (Green 2006; Soler, Soler, and Araya 2017).

\section{CHANGING TECHNOLOGY AND “BLENDED LEARNING”}

The transformation of higher education was due to a variety of changes which included social transformational changes, governmental and economic contexts, and the expansion in higher education. The technological developments also created a dimension and expectation on the use of technology to improve productivity. This, subsequently led to employers gradually realising that the ability of the institution to be innovative and be sustainable relies strongly on staff development and training which are paramount important in equipping staff with technical skills that are essential in using blended learning systems (Garcia Ruiz 2010; Powell 2010; Brooks 2010; Khan, Khan, and Khan 2011).

Blended learning allows for the integration of a diversity of platforms to supplement the delivery of teaching and learning of students, this move has brought about new ways of 
assessing, where online assessments replace classroom activities and allows more online discussions with the lecturer and other students. This does not only replace the traditional method but also allows for creativity in terms of assessing and this change necessitates training of academic staff. The use of blended learning is designed to produce changes in learning patterns and practice, by allowing students to be participative in the learning process as this kind of learning offers greater opportunity to understand the knowledge obtainable (Osguthorpe and Graham 2003; De George-Walker and Keeffe 2010; Singh 2015; Karagiannidis, Politis, and Karasavvidis 2014; Henrich, and Sieber 2010; Irwin, Ball and Desbrow 2012).

\section{The significance of technology adoption in teaching and learning}

With the technological advancement over the years, universities are faced with the challenge of equipping their academic staff with the necessary technological skills, as the progression of technology has resulted in present skills being redundant thereby necessitating the need for institutions of higher learning to ensure that their academic staff is empowered through training to compete with other institutions of higher education, which are providing the same services. While the focus is to enhance education using technology, the only way to effectively use technology in teaching and learning is when institutions have the necessary resource and trained staff to carry out specific training needs of academics (Asfaw et al. 2015; Rana 2017).

Even though academics may not be kept abreast with the use of technology and while some tend to use the traditional method of teaching, literature shows that academics who are neglecting the usage of new technology struggle to apply new approaches of teaching and learning, which subsequently affects the level and quality of blended learning that is increasingly dependent on technology. However, their conceptions change when they start engaging in ICT training sessions, which results in the development of new knowledge and skills, thus training is of utmost importance if institutions of higher learning are going to change the way teaching is currently done (Heirdsfield et al. 2011; Scott 2016). Hubackova and Semradov (2016) claim that the realization of blended learning is also dependent on the student's attitude towards the use of eLearning, the virtual study environment, and their preparedness to go an extra mile when given a task (Oye, Salleh, and Ai.ahad 2010). Therefore, there is an urgent need for higher education institutions to collectively agree to commit to identifying affordable yet engaging workshops that are going to contribute to staff professional development (Cariaga-Lo et al. 2010). In contrast, Islam, Beer and Slack (2015) states that training and development is not the only solution, academics need to change their attitude towards adapting to the use of technology.

Literature shows that the use of technology should not have to replace the lecturer, but should be used to promote teaching and learning, and for the incorporation of technology to be 
a success, academics need to be a bridge between student learning and technology and that can be attained if we have trained lecturers, as academics with more experience prove to be more effective. Furthermore, the use of technology not only benefits the student but also supports learning and allows for online communities for lecturers, where they can share their experiences and fears about change moving away from the traditional method of teaching, while students also enjoy the benefits of ICT, they now have the passion to learn new things through the use of ICT, and this method affords them the chance to get immediate feedback after completion of online assessments, which motivates them to redo the assessment until they can master it (Bester and Brand 2013; Ferreira, Haddad, and Faria 2014; Kler 2014; Woods 2015).

\section{REVOLUTION TEACHING}

The revolution of teaching in universities of higher learning unavoidably consists of several practices, such as research, incorporation of technology, changing teaching practices, and moving towards a learner centred approach. Furthermore, each dimension depends on the lecturers' capabilities because authentic teaching is generally understood as teaching that is concerned with, and fixated on, students and their learning which needs to meet the requirements of the context in which it occurs (Devlin and Samarawickrema 2010; Makondo 2012). Zipin (2013) attests that to embrace the changes in teaching and learning, academics need to show that they recognise their students' identities, acknowledge that they are experts of their lives and that academics desire to learn from them.

In the flipped classroom, the lecturer believes that dynamic learning can be attained through mixing in-class activities with the traditional lecture methods. Furthermore, the lecturer's preparedness to alter old approaches that do not yield positive outcomes is essential to truly shift the practices in a way that supports learner improvement (Weimer 2002; Morrison 2012; Brodie 2013; Roehl, Reddy, and Shannon 2013). Hence, the advantage of the flipped classroom is that lecturers are able to use technology to hold lectures and also video record their lessons and post them online for students to easily access the material at their most convenient time. Moreover, this allows students to work independently before attending classes, and for students who need further assistance, the lesson can be reconsidered and modified to erase any misunderstandings, and this promotes the effective usage of time during teaching and learning (Tucker 2012).

\section{FACTORS THAT INFLUENCE TEACHING AND LEARNING IN HIGHER EDUCATION}

\section{Student diversity}

When lecturing students who come from different academic backgrounds, culture, religious 
groups, race, one should take into consideration that they are unique in their manner, and will have different learning needs which may hinder the effective learning process because the way teaching is conducted influences the ability of students to grasp, utilise and appropriately apply the knowledge they were taught in class (Nyamupangedengu 2017). Furthermore, when conducting lectures, it is vital to acknowledge that teaching practices will differ from one institution to the other as well as from classroom to classroom. Lecturers will, therefore, be required to be skilled in a way that they know how to adjust to meet the different academic needs of students.

\section{Teacher Dimension}

Academics role is essential in the learning process of their students, so for the successful delivery of teaching and learning in the classroom, the teacher should always be willing to learn, upgrade skills, to promote learning and thereby make learning interesting to students in a way that enables students to develop their thinking (Pavione, Avelino, and Fransisco 2016). Academics should encourage contact with students during lectures and after lecturers, also be willing to give feedback to students and most of all have knowledge of the subject matter.

\section{Instructional material}

Learning material is prepared and used to facilitate teaching and learning by academics and designed to improve and support student learning (Huang and Hew 2017). Ajoke (2017) attests that learning material plays a vital role in student learning and also for practicality, it allows academics to present their lessons logically, aids academics in explaining, and encourages student participation.

\section{RESEARCH METHODOLOGY}

For the purpose of this research study, a quantitative research method was utilised to help support and complement the achievement of the primary aim and objectives of this study. Data was collected from academic staff at the Durban University of Technology comprising of six faculties. With the usage of questionnaires, data was collected from 200 participants within the six faculties. A purposive sampling was deemed to be appropriate to be utilised for the selection and identification of the study sample size.

\section{Questionnaire design}

A Likert scale form of the questionnaire was designed through the objectives of the study and literature review to meet the study objectives. The questionnaire was used to collect data about 
the key variables to enable the researcher to clarify the impact of academic training programmes on improving teaching and learning.

\section{Data analysis}

Primary data gathered was coded and cross-checked for any inconsistencies before analysis. This was conducted to ensure that the results were free of error and also reliable for interpretation. A descriptive analysis using the SPSS version (version 23.0) was conducted.

\section{Validity and reliability}

To improve validity and the reliability of data collection instrument, the questionnaire was sent to research expects to check whether the instrument covered all crucial variables, and also to ensure that questions asked had no ambiguity. Secondly, to achieve the study aim and objectives, the questionnaire was piloted to 10 per cent of the sample size, and to also check whether the study questions were effective and reliable. The results from the pilot study ensured the quality of the instrument. To measure and ensure reliability, the same questionnaire was sent to a different group to check for any inconsistencies and ambiguity that may have occurred during the development of the instrument. This process was considered appropriate and reliable in ensuring the quality and the reliability of the questionnaire. It must be noted that the participants to the pilot study were excluded in the main study.

\section{RESEARCH FINDINGS AND DISCUSSION}

This section presents descriptive analysis and the findings are presented in tables. Table 1 reflects the level of adequacy and significance of the sample size for this study.

\section{KAISER-MEYER-OLKIN MEASURE AND BARTLETT'S TEST}

Table 1: KMO and Bartlett's test

\begin{tabular}{|l|l|c|}
\hline \multicolumn{2}{|c|}{ Kaiser-Meyer-Olkin Measure of Sampling Adequacy } & 0.715 \\
\hline \multirow{3}{*}{$\begin{array}{l}\text { Bartlett's Test of } \\
\text { Sphericity }\end{array}$} & Approx. Chi-Square & 287.341 \\
\cline { 2 - 3 } & Df & 55 \\
\cline { 2 - 3 } & Sig. & 0.000 \\
\hline
\end{tabular}

The situations are fulfilled for factor analysis, meaning, the Kaiser-Meyer-Olkin Measure of sampling adequacy value should be greater than 0.500 and the Bartlett's Test of Sphericity sig. value should be less than 0.05 . The results show that there are adequate items for each factor. This portrays that the sample size for this study was adequate for factor analysis. 


\section{RELIABILITY TEST}

Table 2: Reliability score

\begin{tabular}{|c|c|c|}
\hline \multicolumn{1}{|c|}{ Section } & Number of Items & Cronbach's Alpha \\
\hline $\begin{array}{l}\text { Academic training programs } \\
\text { for academics }\end{array}$ & 10 & 0.640 \\
\hline
\end{tabular}

The two most significant aspects of precision are reliability and validity. A reliability coefficient of 0.60 or greater is deemed "acceptable" for a newly developed construct. Cronbach's Alpha for the independent variable which is, on average 0.60 and above, is suitable in most research scenarios (Drost 2011). This means that a recorded score of 0.640 was more than acceptable for the reliability test.

The following statements are based on academic staff training programmes offered by the university. These statements were designed to establish whether the selected university provided academic training programmes essential for staff development.

\section{The university offers academic training programmes}

Table 3: Academic training offered by the university

\begin{tabular}{|c|c|c|c|c|c|}
\hline & & Frequency & Per cent & $X^{2}$ & P-value \\
\hline \multirow[t]{6}{*}{ Valid } & Strongly Agree & 36 & 27.9 & \multirow{5}{*}{$\begin{array}{c}169.109 \\
4\end{array}$} & \multirow{5}{*}{0.000} \\
\hline & Agree & 79 & 61.2 & & \\
\hline & Neutral & 7 & 5.4 & & \\
\hline & Disagree & 2 & 1.6 & & \\
\hline & Strongly Disagree & 4 & 3.1 & & \\
\hline & Total & 128 & 99.2 & & \\
\hline Missing & System & 1 & 0.8 & & \\
\hline \multicolumn{2}{|l|}{ Total } & 129 & 100.0 & & \\
\hline
\end{tabular}

Based on Table 3, a significant number of the respondents 79 (61.2\%) agreed and 36 (27.9\%) further strongly agreed that the university provided academic training programmes. Very few $7(5.4 \%)$ respondents were neutral to the statement and only $4(3.1 \%)$ and $2(1.6 \%)$ strongly disagreed and disagreed that the university provided academic training to academic staff. These findings indicate that academic staff were aware of academic training programmes that the selected UoT offered to academic staff development.

A Chi-square test was computed to establish whether the university offered academic training programmes to academic staff. The findings show that $\left(X^{2}=169.109 ; \mathrm{df}=4 ; \mathrm{P}=0.000\right)$ for this variable, reflecting that academic training programmes were initiated by the selected university. 


\section{Academic training programmes cover areas of interest}

Table 4: Academic training programmes cover areas of interest

\begin{tabular}{|c|c|c|c|c|c|}
\hline & & Frequency & Per cent & $\mathrm{X}^{2}$ & P-value \\
\hline \multirow[t]{6}{*}{ Valid } & Strongly Agree & 22 & 17.1 & \multirow{5}{*}{54.063} & \multirow{5}{*}{0.000} \\
\hline & Agree & 48 & 37.2 & & \\
\hline & Neutral & 39 & 30.2 & & \\
\hline & Disagree & 17 & 13.2 & & \\
\hline & Strongly Disagree & 1 & 0.8 & & \\
\hline & Total & 127 & 98.4 & 100.0 & \\
\hline Missing & System & 2 & 1.6 & & \\
\hline \multicolumn{2}{|l|}{ Total } & 129 & 100.0 & & \\
\hline
\end{tabular}

Based on Table 4, just above 50 per cent of the respondents agreed 48 (37.2\%) and strongly agreed $22(17.1 \%)$ that academic training programmes improve academics capabilities. A noticeable number $39(30.2 \%)$ of the respondents were neutral to the statement, while 17 $(13.2 \%)$ disagreed, with only $1(0.8 \%)$ strongly disagreeing that supported the development and improvement of capabilities of academic staff. This should be a concern to the university as these workshops should accommodate academic staff interest so as to improve their academic progression. These findings were supported by a Chi-square test which was conducted to determine whether academic training programmes offered by the university covered academics areas of interest. The findings show that $\left(\mathrm{X}^{2}=54.063 ; \mathrm{df}=4 ; \mathrm{P}=0.000\right)$ for this variable, reflecting that academic training programmes did not fully cover or accommodated academics areas of interest. It can, therefore, be assumed that these academic training programmes were of general nature and did not focus intensively on each specialisation.

\section{My teaching techniques are improved by the academic staff training programmes offered by the university}

Table 5: My teaching techniques are improved by the academic staff training programmes offered by the university

\begin{tabular}{|l|l|c|c|c|c|}
\hline \multicolumn{2}{|c|}{} & Frequency & Per cent & $\mathbf{X}^{\mathbf{2}}$ & P-value \\
\hline \multirow{4}{*}{ Valid } & Strongly Agree & 33 & 25.6 & & \multirow{3}{*}{0.000} \\
\cline { 2 - 4 } & Agree & 84 & 65.1 & \multirow{2}{*}{137.24} & \\
\cline { 2 - 4 } & Neutral & 7 & 5.4 & & \\
\cline { 2 - 4 } & Disagree & 1 & 0.8 & & \\
\cline { 2 - 4 } & Total & 125 & 96.9 & 100.0 & \\
\hline Missing & System & 4 & 3.1 & & \\
\hline
\end{tabular}

Based on Table 5, the majority of the respondents 84 (65.1\%) agreed and a further $33(25.6 \%)$ strongly agreed that academic staff training programmes improved academic staff capabilities, 
particularly teaching techniques that are essential for teaching and learning. Very few respondents $7(5.4 \%)$ were neutral with only $1(08 \%)$ disagreeing with the statement. These findings clearly indicate that academic staff viewed academic training workshops as a critical component of teaching and learning, especially in terms of capacity development. These findings are supported by a Chi-square test which was conducted to determine whether academic staff training programmes had any influence on teaching techniques. The findings show that $\left(\mathrm{X}^{2}=137.24 ; \mathrm{df}=3 ; \mathrm{P}=0.000\right)$ for this variable, reflecting that academic training programmes positively influence teaching techniques of academic staff.

\section{The transformation of teaching and learning is significantly influenced by academic staff training programmes}

Table 6: The transformation of teaching and learning is significantly influenced by academic staff training programmes

\begin{tabular}{|c|c|c|c|c|c|}
\hline & & Frequency & Per cent & $\mathrm{X}^{2}$ & P-value \\
\hline \multirow[t]{5}{*}{ Valid } & Strongly Agree & 23 & 17.8 & \multirow{4}{*}{138.254} & \multirow{4}{*}{0.000} \\
\hline & Agree & 87 & 67.4 & & \\
\hline & Neutral & 15 & 11.6 & & \\
\hline & Disagree & 1 & 0.8 & & \\
\hline & Total & 126 & 97.7 & 100.0 & \\
\hline Missing & System & 3 & 2.3 & & \\
\hline \multicolumn{2}{|l|}{ Total } & 129 & 100.0 & & \\
\hline
\end{tabular}

Based on Table 6, a significant number of the respondents 87 (67.4\%) agreed and a further 23 $(17.8 \%)$ strongly agreed that academic staff training programmes influenced transformation of teaching and learning. Very few respondents 15 (11.6\%) were neutral to the statement, while only $1(0.8 \%)$ disagreed that training influenced the transformation of teaching and learning. These findings clearly indicate that the transformation of teaching is significantly influenced by training that is purposeful and direct. A Chi-square test that was conducted to determine whether the transformation of teaching is positively influenced by training, the findings reflected that $\left(\mathrm{X}^{2}=138.254 ; \mathrm{df}=3 ; \mathrm{P}=0.000\right)$ for this variable, reflecting that training positively influences the transformation of teaching within selected higher education institution.

\section{Academic staff training offers international teaching and learning approaches}

Table 7: Academic staff training offers international teaching and learning approaches

\begin{tabular}{|l|l|c|c|c|c|}
\hline \multicolumn{2}{|c|}{} & Frequency & Per cent & $\mathbf{X}^{\mathbf{2}}$ & P-value \\
\hline \multirow{3}{*}{ Valid } & Strongly Agree & 19 & 14.7 & \multirow{2}{*}{46.232} & \multirow{2}{*}{0.000} \\
\cline { 2 - 4 } & Agree & 54 & 41.9 & Sd=3 & \\
\cline { 2 - 4 } & Neutral & 45 & 34.9 & & \\
\hline
\end{tabular}




\begin{tabular}{|l|l|c|c|c|c|}
\hline \multicolumn{2}{|c|}{} & Frequency & Per cent & $\mathbf{X}^{2}$ & P-value \\
\hline \multirow{2}{*}{} & Disagree & 7 & 5.4 & & \\
\cline { 2 - 6 } & Total & 125 & 96.9 & 100.0 & \\
\hline Missing & System & 4 & 3.1 & & \\
\hline Total & 129 & 100.0 & & \\
\hline
\end{tabular}

Based on Table 7, a significant number of the respondents 54 (41.9\%) agreed and a further 19 $(14.7 \%)$ strongly agreed that academic staff training programmes provided international teaching and learning methods. A noticeable number of the respondents $45(34.9 \%)$ were neutral to the statement while only $7(5.4 \%)$ disagreed that training was of international standards. Based on the findings, this means that just above half of the respondents viewed and believed that the selected university provided training workshops that provided internationally recognised teaching and learning methods. These findings clearly indicate that not all academic staff viewed these academic staff training workshops to be of international accreditation. A Chisquare test that was conducted further revealed that $\left(\mathrm{X}^{2}=46.232 ; \mathrm{df}=3 ; \mathrm{P}=0.000\right)$ for this variable, indicating that there was inconsistencies in the perceptions of the participants pertaining to whether the offered academic training programmes provided world-class teaching methods. Furthermore, these findings provide an important view in that the selected universities should make it a priority to align its training workshops to those of international standards if they are to compete with prestigious universities around the globe.

\section{Student pass rate is significantly influenced by academic staff training}

Table 8: student pass rate is significantly influenced by academic staff training

\begin{tabular}{|l|l|c|c|c|c|}
\hline \multicolumn{2}{|c|}{} & Frequency & Per cent & $\mathbf{X}^{2}$ & P-value \\
\hline Valid & Strongly Agree & 24 & 18.6 & & \\
\cline { 2 - 4 } & Agree & 69 & 53.5 & \multirow{4}{*}{121.698} & \multirow{2}{*}{0.000} \\
\cline { 2 - 4 } & Neutral & 30 & 23.3 & & \\
\cline { 2 - 4 } & Disagree & 2 & 1.6 & & \\
\cline { 2 - 4 } & Strongly Disagree & 1 & 0.8 & & \\
\cline { 2 - 4 } & Total & 126 & 97.7 & 100.0 & \\
\hline Missing & System & 3 & 2.3 & & \\
\hline \multicolumn{2}{|l|}{ Total } & 129 & 100.0 & & \\
\hline
\end{tabular}

Based on Table 8 above, a significant number of the respondents $69(53.5 \%)$ agreed and a further $24(15.6 \%)$ strongly agreed that academic staff training had a positive influence on student pass-rates. Very few respondents $30(23.3 \%)$ were neutral, with $2(1.6 \%)$ and $1(0.8 \%)$ disagreeing and strongly disagreed with the statement respectively. The findings clearly show that the majority of the respondents believed that student pass-rate is greatly influenced by 
academic training workshop which is key to capacity development. This also indicates that these training programmes can improve the way student assessments are conducted. These findings are supported by a Chi-square test that was conducted to determine whether academic staff training had a positive influence on student pass rate, the findings reflected that $\left(\mathrm{X}^{2}=121.698 ; \mathrm{df}=4 ; \mathrm{P}=0.000\right)$ for this variable, reflecting the academic staff training had a positive and important influence of student pass-rate, which subsequently improves student's completion rate.

\section{Academic staff training programmes improves intellectual capacity}

Table 9: Academic staff training programmes improves intellectual capacity

\begin{tabular}{|l|l|c|c|c|c|}
\hline \multicolumn{2}{|c|}{} & Frequency & Per cent & $\mathbf{X}^{2}$ & P-value \\
\hline Valid & Strongly Agree & 18 & 14.0 & & \\
\cline { 2 - 4 } & Agree & 73 & 56.6 & \multirow{4}{*}{79.576} & \multirow{2}{*}{0.000} \\
\cline { 2 - 4 } & Neutral & 26 & 20.2 & & \\
\cline { 2 - 4 } & Disagree & 8 & 6.2 & & \\
\cline { 2 - 4 } & Total & 125 & 96.9 & & \\
\hline Missing & System & 4 & 3.1 & & \\
\hline Total & 129 & 100.0 & & \\
\hline
\end{tabular}

Based on Table 9, the significant number of the respondents 73 (56.6\%) agreed and a further $18(14.0 \%)$ strongly agreed that academic staff training programmes improve intellectual capacity. Very few respondents $26(20.2 \%)$ were neutral to the statement while only $8(6.2 \%)$ felt that the training programmes were not improving academic staff intellectual capacity. These findings clearly indicate that academic staff's training workshops were not in all totality in terms of whether academic staff training workshop improved their intellectual capacity - this is reflected by slightly above half of the respondents. These findings are supported by a Chisquare test that was conducted to determine whether academic staff training improved the intellectual capacity of staff. The findings reflected that $\left(\mathrm{X}^{2}=79.576 ; \mathrm{df}=3 ; \mathrm{P}=0.000\right)$ for this variable, reflecting academic staff did not believe that their intellectual capacity was solely dependent on academic staff training workshops provided by the university.

\section{Training programmes are interesting and encouraged critical thinking}

Table 10: Training programmes are interesting and encouraged critical thinking

\begin{tabular}{|l|l|c|c|c|c|}
\hline & & Frequency & Per cent & $\mathbf{X}^{2}$ & P-value \\
\hline \multirow{3}{*}{ Valid } & Strongly Agree & 17 & 13,2 & & \\
\cline { 2 - 4 } & Agree & 43 & 33,3 & \multirow{3}{*}{77.685} & 0.000 \\
\cline { 2 - 4 } & Neutral & 54 & 41,9 & & \\
\hline
\end{tabular}




\begin{tabular}{|l|l|c|c|c|c|}
\hline & & Frequency & Per cent & $\mathbf{X}^{\mathbf{2}}$ & P-value \\
\hline \multirow{7}{*}{} & Disagree & 12 & 9,3 & & \\
\cline { 2 - 4 } & Strongly Disagree & 1 & 0,8 & & \\
\cline { 2 - 5 } & Total & 127 & 98,4 & 100,0 & \\
\hline Missing & System & 2 & 1,6 & & \\
\hline Total & 129 & 100,0 & & \\
\hline
\end{tabular}

Based on Table 10, interestingly, slightly more than half of the respondents were either neutral $54(41.9 \%)$, disagreed $12(9.3 \%)$ or strongly disagreed $1(0.8 \%)$ with the statement on whether training programmes were interesting and encouraged critical thinking amongst academics. Slightly below half of the respondents agreed with the statement, with 43 (33.3\%) agreeing and $17(13.2 \%)$ further strongly agreed that training programmes were interesting and triggered critical thinking. These findings are supported by a Chi-square test that was conducted and the findings reflected that $\left(\mathrm{X}^{2}=77.685 ; \mathrm{df}=4 ; \mathrm{P}=0.000\right)$ for this variable, reflecting that the training programmes were somehow lacking in various aspects, particularly in encouraging staff critical thinking.

\section{Training is provided on technological teaching and learning tools}

Table 11: Training is provided on technological teaching and learning tools

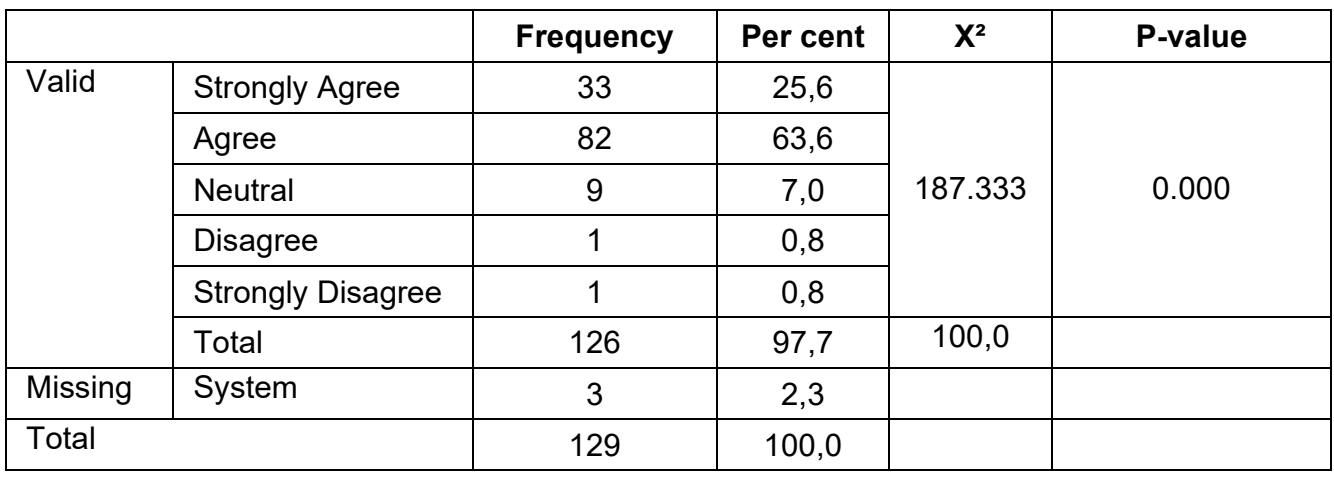

Based on Table 11 above, a significant number of the respondents $82(63.6 \%)$ agreed and 33 (25.6\%) further strongly agreed that training is provided on technological teaching and learning tools. Very few respondents $9(7.0 \%)$ were neutral to the statement and only $1(0.8 \%)$ strongly disagreed and disagreed with the statement. These findings clearly show that the university provides training support on how to utilise technological or online teaching and learning tools. This means that the university has invested in modern teaching and learning approaches by introducing the element of online teaching. These findings are sustained by a Chi-square test that was conducted to determine whether training was provided on technological teaching and learning tools, the findings reflected that $\left(\mathrm{X}^{2}=187.333 ; \mathrm{df}=4 ; \mathrm{P}=0.000\right)$ for this variable, showing that the university supported academic staff by offering training on technological teaching and learning tools. 


\section{Training is provided for integrating technology into curriculum}

Table 12: Training is provided for integrating technology into curriculum

\begin{tabular}{|l|l|c|c|c|c|}
\hline \multicolumn{2}{|c|}{} & Frequency & Per cent & $\mathbf{X}^{\mathbf{2}}$ & P-value \\
\hline \multirow{7}{*}{ Valid } & Strongly Agree & 40 & 31,0 & & \\
\cline { 2 - 4 } & Agree & 69 & 53,5 & \multirow{3}{*}{84.095} & \multirow{2}{*}{0.000} \\
\cline { 2 - 4 } & Neutral & 16 & 12,4 & 3 & \\
\cline { 2 - 4 } & Disagree & 1 & 0,8 & & \\
\cline { 2 - 4 } & Total & 126 & 97,7 & & \\
\hline Missing & System & 3 & 2,3 & & \\
\hline Total & 129 & 100,0 & & \\
\hline
\end{tabular}

Based on Table 12, a significant number of the respondents $69(53.5 \%)$ agreed and $40(31.0 \%)$ strongly agreed that training was provided for integrating technology into curriculum. Very few respondents $16(12.4 \%)$ were neutral to the statement and only $1(0.8 \%)$ disagreed that training was provided for integrating technology into the curriculum. These findings clearly show that more than 80 per cent of the respondents believed that the university assisted in the transformation of the curriculum. These findings further indicate that the university if a firm believer in technology and that transformation of teaching and learning needs to be in sync with the current technologies being used worldwide. These findings are supported by Chi-square test that was conducted to determine whether Training is provided for integrating technology into the curriculum, the findings reflected that $\left(\mathrm{X}^{2}=184.095 ; \mathrm{df}=3 ; \mathrm{P}=0.000\right)$ for this variable, indicating that the support offered by the university is of integral need for the transformation of student curriculum.

\section{CONCLUSIONS AND RECOMMENDATIONS}

The following section covers the conclusions and recommendations deriving from the empirical findings, aims, and objectives of this study.

\section{CONCLUSIONS}

It is clear that based on the findings of the study; academic training workshops offered by the selected university of technology were relatively in line with the expectations of academic staff. Most importantly, these workshops were identified to be influential in terms of capacitating and developing academic staff in terms of technical skills and providing internationally recognised teaching and learning methods or techniques, which are critically needed to support the development and sustainability of teaching and learning within the institution. However, it must 
be made clear that the respondents, to a certain extent were not satisfied with the quality of the training provided, particularly, on whether the training programmes were interesting and encouraged critical thinking and on whether it improved intellectual capacity. Therefore, this study concludes that in order for the university to fully understand the impact of these academic training workshops, a systematic review should be conducted to establish the level of influence these workshops have on academic staff intellectual capabilities, teaching and learning methods and how it subsequently influence student pass-rate. Since these academic training programmes were identified as significant contributors to the transformation of teaching and learning within the selected university, then, key strategic approaches should be made to monitor, co-ordinate and control how these training workshops influence teaching and learning. It can also be concluded that based on the empirical findings of this study, the training programmes which were provided were general and did not extensively provide field related approaches that would significantly improve teaching and learning of academics in respective departments and or faculties.

\section{RECOMMENDATIONS}

In line with the aims, objectives and empirical findings of the study, since these workshops are provided at an institutional level, it is recommended that they are to be provided and monitored at a departmental and or faculty level. This will help the institution to review with a fine lance on whether the provided academic training programmes benefit all academic staff. Considering that the university has multiple diverse faculties, it would be much more effective if the institution organise academic training workshops that are field related rather than using a "one size fits all" type of an approach. It is further recommended that the university should not be solely responsible for identifying and selecting academic training programmes, however, the inclusion of academic staff during the identification and selection of these academic training programmes will be of great benefit to academic staff and the institution. The academic staff will be attending these training programmes because they purely need them rather than being forced to attend them. The university, on the other hand, will not be investing and spending hefty monies on training programmes that are not in line with the needs of the academic staff. Therefore, in order to determine the impact of these academic training programmes, the university needs to formulate a strategic review process at a departmental and or faculty level that will assess certain pillars that contribute and support academic staff capacity development which should subsequently inform teaching and learning. 


\section{REFERENCES}

Abdelmalak, M. and J. Trespalacios. 2013. "Using a learner-centered approach to develop an educational technology course." International Journal of Teaching and Learning in Higher Education 25(3): 324-332.

Ajoke, A. R. 2017. "The importance of instructional materials in teaching English as a Secondary language.” International Journal of Humanities and Social Science Invention 6(9): 36-44.

Akinfolarin, A. V. 2014. "Role of Sport in Education. Eagle Reporters." Nigerian Online Newspaper. http://eaglereporters.com/2014/06/16/role-of-sport-in-educationbyakinfolarin-akinwale-v-b-ed/ (Accessed 3 September 2019).

Al-adwan, A. and J. Smedley. 2012. "Implementing e-learning in the Jordanian Higher Education System: Factors affecting impact." International Journal of Education and Development Using Information and Communication Technology 8(1): 121-135.

AL-Mutairi, A. 2011. "Factors Affecting Business Student's Performance in Arab Open University: Case of Kuwait." International Journal of Business and Management 6(5): 146-155.

Asfaw, A. M., M. D. Argaw and L. Bayissa. 2015. "The Impact of Training and Development on Employee Performance and Effectiveness: A Case Study of District Five Administration Office, Bole Sub-City, Addis Ababa, Ethiopia." Journal of Human Resource and Sustainability Studies 3: $188-202$.

Ball, D. L. and G. W. McDiarmid. 2016. The subject matter preparation of teachers. Houston. W.R. Handbook for Research on Teacher Education. New York: Mackmillan.

Balyer, A., K. Özcan, and A. Yildiz. 2017. "Teacher Empowerment: School Administrators' Roles.” Eurasian Journal of Educational Research 70: 1-18.

Bester, G. and L. Brand. 2013. "The effect of technology on learner attention and achievement in the classroom." South African Journal of Education 33(2): 1-15.

Brodie, K. 2013. "The power of professional learning communities." Education as Change 17(1): 5-18.

Brooks, C. F. 2010. "Toward 'hybridised' faculty development for the twenty first century: Blending online communities of practice and face-to-face meetings in instructional and professional support programmes." Innovations in Education and Teaching International 47(3): 261-270.

Cariaga-Lo, L., P. Worthy Dawkins, R. Enger, A. Schotter, and C. Spence. 2010. "Supporting the development of the professoriate." Peer Review 12(3): 19-22.

Chan, R. Y. 2016. "Understanding the purpose of higher education: An analysis of the economic and social benefits for completing a college degree." Journal of Education Policy, Planning and Administration 6(5): 1-41.

CHE. 2013. The aims of higher education. https:/www.che.ac.za/sites/default/files/publications/ kagisano9.pdf (Accessed on 15 January 2019).

Costly, K. C. 2014. The positive effects of technology on teaching and student learning. Arkansas Tech University. Online submission. ERIC - ED554557 - The Positive Effects of Technology on Teaching and Student Learning, Online Submission, 2014-Oct-30. (Accessed 16 April 2021).

De George-Walker, L. and M. Keeffe. 2010. "Self-determined blended learning: A case study of blended learning design." Higher Education Research and Development 29(1): 1-13.

Devlin, M. and G. Samarawickrema. 2010. "The criteria of effective teaching in a changing higher education context." Higher Education Research and Development 29(2): 111-124.

Drost, E. A. 2011. "Validity and reliability in social science research." Education Research and Perspectives 38(1): 105-124. http://search.proquest.com/docview/1020696142?accountid=10612 (Accessed 16 February 2019).

Elnaga, A. and A. Imran. 2013. "The Effect of Training on Employee Performance." European Journal of Business Management 5: 137.

Fernández, T. J. 2013. "Professionalisation of teaching in universities: Implications from a training 
perspective." Universities and Knowledge Society Journal 10(1): 345-358.

Ferreira, N. S. C., M. E. O. Haddad, and A. A. Faria. 2014. "Educational technology and educational management in the higher education: New ways of forming professionals." Open Journal of Social Sciences 02(02): 7-11.

Finch, D. J., M. Peacock, N. Levallet, and W. Foster. 2016. A dynamic capabilities view of employability: Exploring the drivers of competitive advantage for university graduates. Education + Training 58(1): 61-81. https://www.emeraldinsight.com/doi/pdfplus/10.1108/ET-02-20150013 (Accessed 11 October 2019).

Garcia Ruiz, M. J. 2010. "Implications of the new social characteristics of knowledge production.” In Changing educational landscape. Education Policies, Schooling Systems and Higher Educationa Comparative Perspective. London: Springer.

Green, A. 2006. "University challenge: Dynamic subject knowledge, teaching and transition." Arts and Humanities in Higher Education 5(3): 275-290.

Hanaysha, J. 2016. "Examining the Effects of Employee Empowerment, Teamwork, and Employee Training on Organizational Commitment." Procedia - Social and Behavioral Sciences 229: 298306.

Heirdsfield, A., S. Walker, M. Tambyah, and D. Beutel. 2011. Blackboard as an online learning environment: What do teacher education students and staff think? Australian Journal of Teacher Education (Online) 36(7): 1-16.

Henrich, A. and S. Sieber. 2010. Hybrid learning: "Neither fish nor fowl" or "The golden mean", ed. P. Tsang, 82-93. Springer

Huang, B. and K. F. Hew. 2017. Factors influencing learning and factors influencing persistence: A mixed-method study of MOOC learners' motivation. In Proceedings of the 2017 International Conference on Information Systems and Data Mining, 103-110.

Hubackova, S. and I. Semradov. 2016. "Evaluation of Blended Learning." Procedia Social and Behavioral Sciences 217: 551-557.

Irwin, C., L. Ball, and B. Desbrow. 2012. "Students' perceptions of using Facebook as an interactive learning resource at university." Australasian Journal of Educational Technology 28(7): 12211232.

Islam, N., M. Beer, and F. Slack. 2015. "E-learning challenges faced by academics in higher education." Journal of Education and Training Studies 3(5): 102-112.

Kang'ahi, M., F. C. Indoshi, T. O. Okwach, and J. Osido. 2012. "Teaching styles and Learners' Achievement in Kiswihili Language in Secondary Schools." International Journal of Academic Research in Progressive Education and Development 1(3): 62-87.

Karagiannidis, C., P. Politis, and I. Karasavvidis. 2014. Research on e-Learning and ICT in Education. Springer.

Karthikeyan, K., R. Karthi, and S. Graf. 2010. "Impact of training in the Indian banking sector - an empirical study." International Journal of Business Management 5(7): 77-83.

Khan, R. A. G., F. A. Khan, and M. A. Khan. 2011. "Impact of Training and Development on Organisational Performance." Global Journal of Management and Business Research 11: 61-68.

Kler, S. 2014. "ICT Integration in teaching and learning: Empowerment of education with technology." Issues and Ideas in Education 2(2): 255-271.

Kumar, D. and H. Siddika. 2017. "Benefits of training and development programme in employees' performance: A study with special reference to banking sector in Bangladesh." International Journal of Research Granthaalayah 5(12): 77-88.

Makondo, L. 2012. Mindset change prerequisite for academic excellence: A case of four Zimbabwean and South African Universities. South African Journal of Higher Education 26(1): 105-119.

McDowall, A. and M. N. K. Saunders. 2010. "UK managers Conceptions of Training and Development." Journal of European Industrial Training 34: 609-630. http://dx.doi.org/ 
10.1108/03090591011070752 (Accessed 12 August 2019).

Moloi, K. C., T. S. Mkwanazi, and T. P. Bojabotseha. 2014. "Higher Education in South Africa at the Crossroads." Mediterranean Journal of Social Sciences 5(2): 469-475.

Morrison, C. 2012. "From sage on the stage to guide on the side: A good start." International Journal for the Scholarship of Teaching and Learning 8(1): 1-23.

Newland, B. and L. Byles. 2014. "Changing academic teaching with Web 2.0 technologies." Innovations in Education and Teaching International, 51(3): 315-325. https://srhe.tandfonline.com/doi/pdf/ 10.1080/14703297.2013.796727?needAccess=true (Accessed 11 October 2019).

Nyamupangedengu, E. 2017. "Investigating factors that impact the success of students in a Higher Education classroom: A case study." Journal of Education 68: 113-130.

Osguthorpe, T. R. and R. C. Graham. 2003. "Blended learning environments." Quarterly Review of Distance Education 4(3): 227-233.

Oye, N. D., M. Salleh, and N. Ai.ahad. 2010. "Holistic E-learning in Nigerian Higher Education Institutions." Journal of Computing 2(11): 20-26.

Paolini, A. 2015. "Enhancing Teaching Effectiveness and Student Learning Outcomes." The Journal of Effective Teaching 15(1): 20-33.

Pavione, C. S. S. N., B. M. Avelino, and J. R. S. Fransisco. 2016. "Factors that influence the TeachingLearning Process from the perspective of Accountancy Students: Analysis at a higher Education Institution in Minas Gerais." Journal of Education and Research in Accounting 10(2): 192-215.

Powell, T. 2010. "What motivates faculty to adopt distance learning?" International Journal on Advances in Life Sciences 2(3/4): 173-187.

Rana, K. S. 2017. "Use of technologies in teaching and learning activities: strategies and challenges." MTech, University of Olso.

Rahman, A. A., I. S. Ng, M. Sambassivan, and F. Wong. 2013. "Training and Organisational Effectiveness: Moderating Role of Knowledge Management Process." European Journal of Training and Development 37: 478-488.

Randall, M. M. and J. A. Cox. 2015. "Learner-Centered Pedagogy: Considerations for application in a Didactic Course." The Professional Counselor 5(3): 379-389.

Roehl, A., S. Reddy, and G. Shannon. 2013. "The flipped classroom: An opportunity to engage millennial students through active learning strategies." Journal for Family and Consumer Sciences 105(2): 44-49.

Salah, M. R. A. 2016. "The Impact of Training and Development on Employees Performance and Productivity." International Journal of Management Sciences and Business Research 5(7): 3670.

Sabir, R. I., N. Akhtar, S. Azzi, B. Sarwa, S. Zulfigar, and M. Irfan. 2014. "Impact of Employee Satisfaction: A study of Lahore Electric Supply Company of Pakistan." Journal of Basic and Applied Scientific Research 4: 229-235.

Scott, K. M. 2016. "Change in university teachers' elearning beliefs and practices: a longitudinal study." Studies in Higher Education 41(3): 582-598.

Seyoum, Y. 2012. "Staff development as an imperative avenue in ensuring quality: The experience of Adama University." Education Research International: 1-18.

Singh, R. J. 2015. "Use of blended learning in higher education - some experiences." South African Journal for Open and Distance Learning Progressio 37(1): 54-67.

Soler, R., J. R. Soler, and I. Araya. 2017. "Subjects in blended learning model design. Theoreticalmethodological elements." Procedia Social and Behavioural Sciences 237: 771-777.

Tucker, B. 2012. "The flipped classroom.” Education Next 12(1). http://educationnext.org/the-flippedclassroom/ (Accessed 10 December 2019).

Wickramasinghe, V. M. 2006. Training objectives, transfer, validation and evaluation: a Sri Lankan 
study. International Journal of Training and Development 10(3): 227-247.

Williams, K. C. and C. C. Williams. 2011. "Five key ingredients for improving student motivation." Research in Higher Education Journal 12: 104-122.

Winach, P. and L. Meyer. 2013. "Trainee teachers' observation of learner-centred instruction and assessment as applied by History and Social Sciences Teachers." Yesterday and Today 9: 13-32.

Weimer, M. 2002. Learner-centered teaching: Five key changes to practice. San Francisco, CA: JosseyBass.

Woods, M. 2015. "Technology integration: How effective are teachers at implementing technology into classroom instruction." Mtech, Vancouver Island University.

Zipin, L. 2013. "Engaging middle year's learners by making their communities curricular." Curriculum Perspectives 33(3): 1-12. 